\title{
INTERNATIONAL COOPERATION AND MANAGEMENT IN GLOBAL ENVIRONMENT AND SUSTAINABLE DEVELOPMENT
}

\author{
Andrzej Mirski \\ PhD, University of Science and Technology in Krakow, e-mail: artmir@o2.pl, Poland \\ Andrii Shaikan \\ Prof. DSc, Kryvyi Rih Economic Institute of Kyiv National Economic University named after \\ Vadym Hetman, e-mail: director@kneu.edu.ua, orcid.org/0000-0002-4088-6518, Ukraine \\ Abraham Kome \\ Dr, John Pall II International University of Bafang, \\ e-mail: k_abra2006@yahoo.fr, orcid.org/0000-0001-7326-227X, Cameroon
}

\begin{abstract}
Environmental management can no longer only be of local importance, as globalization processes have also embraced this area. The author distinguished and discussed six aspects of ecological globalization: proximity, interdependence, awareness, attitudes and responsibility, and interaction.
\end{abstract}

Keywords: Globalization, Ecological globalization, proximity, interdependence, awareness, attitudes and responsibility, interaction, management, sustainable development.

DOI: http://dx.doi.org/10.23856/2403

\section{Introduction}

Globalization is the action or procedure of international integration arising from the interchange of world views, products, ideas, and other aspects of culture (Albrow, King, 1990). It is a process in which geographical barriers are lost, while at the same time increasing awareness in societies. Globalization in an objective sense means the real processes of disappearing geographical barriers on the globe in various ways: economic, cultural, social, legal, ecological, etc. On the other hand, globalization in the subjective sense (psychological) means the growing awareness of these processes in people. The concept of globalization derives its etymology from the Latin word "globe", hence Webster's dictionary defines the adjective "global" as covering the whole world (Skorupka, Auderska, Łempicka, 1969). Our planet is now defined as a "global village," in which the distances between states disappear. Because these economic barriers refer to different phenomena, the very concept of globalization is interdisciplinary. Globalization refers to different areas. In economic terms, globalization leads to the integration of economies and economic processes in different countries of the world. Globalization in the socio-cultural dimension is the spread of mass cultural patterns, which is often referred to as americanization (Sztompka, 2005). Political globalization means the transfer of decision-making burden from individual states and their ad hoc co-operation to a level of close international co-operation, with the participation of corporations and non-governmental organizations (Zachara, 2012) in addition to states, increasingly fulfilling the functions of state institutions (Załęski, 2005). The concept of globalization also plays a very important role in modern management science. Stoner, Freeman and Gilbert understand globalization as an organization's understanding that business must take into account a global rather than a local point of view (Stoner, Freeman, Gilbert, 
1198). The process of internationalization of enterprises, and the activity of enterprises abroad, is also rapidly taking place (Oczkowska, 2007).

\section{Ecological globalization}

Ecological globalization is a process in which geographic barriers between individual countries disappear and the processes of interdependence and cooperation in the field of ecology are increasing, accompanied by awareness of people and organizations. The author discusses the six most important aspects of ecological globalization: 1. proximity, 2. interdependence, 3. co-operation, 4. awareness, 5. attitudes and 6. responsibility.

Ad. 1. The proximity of ecological processes is chiefly responsible for the rapid development of technology, industrialization and urbanization. Formerly, with low density of inhabitants of the Earth, individual countries were practically independent in terms of their impact on the environment. At present, however, large industrial centers or agglomerations (such as Beijing and New Delhi) produce such large quantities of industrial and municipal dust that, with global air circulation, they also reach other countries. Greenhouse gas production in individual countries also results in global warming. So the ecological borders between different countries and regions disappear.

Ad. 2. Ecological interdependence is a consequence of growing progressive global economic interelations. The best example of this is the so-called transfer of "dirty technologies" consisting in moving production to regions of the lower ecological standards, to minimize production costs. Used electronic devices in rich countries get disposed of as waste to distant poor countries, where their technologically obsolete disposal, based primarily on firing, causes extremely dangerous environmental pollution. Cultural interdependence is also significant, and in particular the adoption of densely populated and poor countries of the world in the world of cultural patterns of consumption characteristic of developed and rich countries. If every Chinese or Indian family wants to own a few cars and consume as much meat and energy as an average American family, these countries will start producing huge amounts of agricultural, industrial and transportation gases, with badconsequences for the global ecological environment

Ad. 3. Global co-operation is another manifestation of the globalization called also environmental governance. It is the sum of organizations, policy instruments, financing mechanisms, rules, procedures and norms that regulate the processes of global environmental protection. The efficacy of global environmental governance will ultimately depend on implementation at global and domestic levels. National implementation is the ultimate key, both to the efficacy of the GEG system and to meaningful environmental improvements. Since environmental issues entered the international agenda in the early 1970s, global environmental politics and policies have been developing rapidly.

Ad. 4. Global ecological awareness means understanding that the boundaries that once separated different niches and ecological areas ceased to exist, that the world is becoming one "ecological village," and that decisions made in economic and political organizations and even in consumer homes now Global reach, not just local.

Ad. 5. Global ecological attitude means that the approach towards globalization must take into account the ecological factor. Naive enthusiasm for globalization may overlook the ecological threats that can be associated with it, the transfer of "dirty technology", the removal of harmful waste or electronic waste, the consequences of large migration movements, etc. Anti-globalization is even more dangerous because it is tempting to confine 
itself to the problem of one's own state, no matter the other, while globalization processes, including ecological globalization, are real, inevitable and growing. The most appropriate attitude is critical globalization, aware of the inevitability of globalization processes, while trying to give it a protective shape for world ecology. Such an attitude can be called "ecological alterglobalism".

Ad.6. Finally, global ecological responsibility is very important. The author proposes to divide it into material, technological, legal, political and cultural.

Materialresponsibility, both at the organization and consumer level, is the simplest and most basic - do not dirty, do not smoke, do not waste, do not pollute the environment, do not waste energy, reduce greenhouse gas emissions, because the consequences of these activities are now global.

Technological responsibility is related to the design and operation of equipment, friendly to the environment. This applies mainly to organizations, managers, academics and technical staff, but also to consumers, such as whether to buy a diesel or electric car.

Political and legal responsibility is related to the establishment of national and international laws and regulations aimed at environmental protection. This responsibility lies primarily with politicians, councilors, deputies, members of governments and international organizations. But it is also the responsibility of all citizens to vote for those parties, organizations and politicians who present programs and projects for environmental protection, whether regional, national or international.

Finally, especially important, often neglected, cultural responsibility. This is primarily about creating, promoting and disseminating patterns of cultural behavior and patterns of consumption that are environmentally friendly and environmentally friendly.

\section{Global Environmental Management}

Global environmental governance is another manifestation of the globalization of cooperation. This cooperation takes place internationally. Global environmental management is not run by one organization, there is not one global ministry of the environment. But central management within a single organization or company is not the only form of management. Griffin's classic definition of organization management is that management is a set of activities (planning, organizing, motivating, controlling) directed at the resources of the organization (human, financial, material, information) used to achieve organizational goals (Stoner, Freeman, Gilbert, 1198). But in the case of state management or local government, this set of actions is directed at the resources of the state (or territorial unit) and is used with the intention of achieving that state (or territorial unit). Moreover, the government is by no means the only organization managing the state, there are many (egParliament, Prosecutor's Office, Constitutional Court and many others). These organizations are jointly undertaking actions directed at state resources to achieve specific objectives, based on a democratic system at the will of the people. The essence of all forms of management is planning, organizing, guiding and controlling, directed at specific resources to achieve specific objectives. Such broadly understood management can be carried out by many different organizations and bodies cooperating with each other. Similarly, in the case of environmental management, using, protecting and shaping the environment, in production processes and during non-productive activity of society and individuals (Oczkowska, 2007).

At the global scale sustainability and environmental management involves managingthe oceans, freshwater systems, land and atmosphere, according to sustainability 
principles (Buchenrieder, Göltenboth, 2003). Land use change is fundamental to the operations of the biosphere because alterations in the relative proportions of land dedicated to urbanisation, agriculture, forest, woodland, grassland and pasture have a marked effect on the global water, carbon and nitrogen biogeochemical cycles. Management of the Earth's atmosphere involves assessment of all aspects of the carbon cycle to identify opportunities to address human-induced climate change and this has become a major focus of scientific research because of the potential catastrophic effects on biodiversity and human communities. Ocean circulation patterns have a strong influence on climate and weather and, in turn, the food supply of both humans and other organisms.

Environmental management is primarily directed at environmental resources and is implemented to protect the environment. The resources to which this management is directed can be subdivided into those that are environmental resources (the purpose is to reproduce, cultivate, regulate, reconstruct, or enrich resources), and material resources (physical, technological, social Financial, legal and informative) that can be collected and used for the purpose of environmental protection.

In the case of global environmental management, the management entity is the entire planet Earth and its resources, with the goal of preserving and developing its environment. It is worth mentioning here that broadly understood environmental management does not refer only to the natural environment but also to the social and cultural environment. Global environmental governance also includes the care of the Earth's cultural heritage (preservation and conservation of monuments, works of art, regional customs and traditions, languages, etc.) and the provision of decent social and material conditions in various areas of the planet. Poverty, excessive social inequalities or violations of human rights or dignity).

Thus the most important overall goal of global environmental governance is to achieve global sustainability. It should be noted that in global environmental management it is necessary to strive for certain compromises and optimizations between natural, cultural and social resources. In order to eradicate poverty, malnutrition, unemployment and provide the people of the world with decent material, social and cultural conditions, further economic growth is needed, thus further industrial development and intensification of agriculture. However, the point is that this development is not at the expense of the natural environment, and this can only be achieved through the high innovativeness of the global economy.

Global environmental management is collective (synergetic). It is characterized by complexity, diversity and institutionalization. The nature of initiating in this management process is played by the International Conferences, enacting binding programs, conventions, laws and agendas, while the executive character has various international institutions. This management also involves local (national) players by implementing internationally agreed principles, resolutions and actions. On the other hand, companies are increasingly influencing the global environment.

\section{International Conferences and Conventions on Global Environmental Management}

International Conferences focused primarily on air protection, water conservation, hazardous waste control, environmental impacts, biodiversity and sustainable development.

International air protection was initiated in 1979. The First World Conference on Climate Change in Geneva, which created the World Climate Program, established the World Meteorological Organization and adopted the first legally binding international instrument for reducing harmful emissions. This topic was further developed by the Helsinki Protocol on the 
reduction of sulfur emissions, which entered into force in 1987, the Sofia Protocol on Nitrogen Emission (1991) and the Aarhus Protocols, on the volatile organic compounds and heavy metals in the air. Particularly important were the arrangements for the protection of the ozone layer, primarily the Montreal Protocol on Substances that Deplete the Ozone Layer, signed by the parties under the Vienna Convention on the Protection of the Ozone Layer (entered into force in 1985).

In the area of international water protection in 1992, the Water Convention was adopted in Bonn to prevent and reduce surface water and groundwater pollution, protect cross-border water flows and international lakes and seas and set common flood protection requirements. Its continuation is the protocol that has been in force since 2005 for the provision of clean drinking water to all communities and to providing them with satisfactory access to sanitary facilities. In 2007, the Conference of the Parties to the Protocol adopted resolutions concerning the mechanisms coordinating these actions (Poskrobko, 1998). With regard to the control of hazardous waste and in particular the control of their transboundary movement and use, the Basel Convention was adopted in 1998 (came into force in 2002). An appropriate protocol was also adopted, defining compensation for damage to the environment and the health of the inhabitants of the affected countries. A very important moment in initiating international environmental governance was the World Summit of the United Nations "Summit of the Earth" in Rio de Janeiro in 1992. This conference has adopted the Framework Convention on Climate Change, the Biodiversity Conventions and the Agenda 21. Despite many subsequent initiatives and agreements, this conference continues to underpin global environmental governance (Möller, 2013).

The Biodiversity Convention entered into force on December 22, 1993 and its signatories are more than 196 countries around the world. The basic objectives of the Convention are the maintenance of biodiversity, the sustainable use of their components, and the fair sharing of the benefits of genetic resources. The concept of biodiversity adopted by the Convention covers the diversity of ecosystems, the diversity of species and the genetic diversity within species. The basic objectives of the Convention are the maintenance of biodiversity, the sustainable use of their components, and the fair sharing of the benefits of genetic resources (Möller, 2013).

\section{The most important institutions involved in global environmental management}

At present, the most important international organization that coordinates global environmental governance through its numerous programs and institutions is the United Nations. Its important environmental program is UNEP (United Nations Environment Program), based in Nairobi, coordinating international activities undertaken by governments, businesses and non-governmental organizations in the field of environmental protection and sustainable development, and organizers of annual environmental ministers from different countries around the world. United Nations Environment Program has overall responsibility for environmental problems among United Nations agencies but talks on addressing global warming are overseen by the Bonn-based Secretariat of the United Nations Framework Convention on Climate Change. Its activities cover a wide range of issues regarding the atmosphere, marine and terrestrial ecosystems, environmental governance and green economy.

The United Nations Developmental Program (UNDP) is a development program established in New York in 1965 to support the technological and financial cooperation of UN 
member states. UNDP is funded entirely by voluntary contributions from member nations. The organization operates in 177 countries, where it works with local governments to meet development challenges and develop local capacity. UNDP works with nations on their own solutions to global and national development challenges.

UNCED (United Nations Conference on Environment and Development) organizes conferences on the environment and development.

The United Nations Commission on Sustainable Development (UNSCD), which is dedicated to promoting sustainable development, is another important UN commission dedicated to international environmental governance.

The broadly understood human environment encompasses not only nature but also culture, education and social development, so the important UN commission in this regard is the United Nations Educational, Scientific and Cultural Organization (UNESCO), based in Paris. Important international initiatives include the International Convention on the World Cultural Heritage and the World Biological Network "Man and Biosphere Program".

The World Bank, based in Washington, DC, was created in 1944 as a special UN organization, initially to assist Member States in rebuilding after war damage with specialized loans. At present, the World Bank's most important goal is to support economies, especially developing countries, by finalizing and advising. Two institutions of the World Bank play a particularly important role: IBRD (International Bank for Reconstruction and Development) and IDA (International Development Association). In support of environmental activities, the World Bank together with UNEP and UNDP established the Global Environment Facility (GEF) in 1991. It especially supports international activities that have a positive impact on the environment. The World Bank publishes important annual reports, such as WDR (World Development Report) and GEP (Global Economic Prospects). The World Bank also participates in financing and financing clean energy investments. In 2007, the World Bank launched the Clean Energy and Development Investment Framework (CEIF) to support sustainable development strategies.

Other important international organizations included in the process of global environmental governance include the Organization for Economic Co-operation and Development (OECD), which aims to support economic development once again by improving the choice of Member States and other developing countries. The OECD operates within the International Energy Agency. Other important organizations in this area include the World Economic Forum, the World Social Forum, the World Union for Conservation, the World Water Council and the World Water Forum.

Many non-governmental organizations have also become involved in the process of global environmental governance. Although they do not themselves constitute international agreements, their influence is very significant, especially in terms of lobbying, important campaigns, licensing of recognized licenses and certification.

An example is Greenpeace, which works to protect the environment around the world. The organization has offices in 55 countries, including Poland.

WWF's World Wide Fund for Nature mission is to halt the degradation of the Earth's natural environment and to create a future where people will live in harmony with nature. Together with IUCN and UNEP, WWF has created a Global Strategy for Nature Conservation, which has provided the basis for a comprehensive look at environmental protection and the sustainable use of our planet's natural resources.

Earth Friends, FoEI (Friends of the Earth International) is a federation of independent ecological organizations, bringing together around 1.5 million members and supporters in 70 
countries, working for local and global sustainable development. In Poland, FoEI is a Polish Ecological Club.

\section{Sustainable development}

Sustainable development is the organizing principle for meeting human development goals while at the same time sustaining the ability of natural systems to provide the natural resources and ecosystem services upon which the economy and society depends. The desirable end result is a state of society where living conditions and resource use continue to meet human needs without undermining the integrity and stability of the natural systems.

As the concept developed, it has shifted to focus more on economic development, social development and environmental protection for future generations. It has been suggested that "the term 'sustainability' should be viewed as humanity's target goal of human-ecosystem equilibrium (homeostasis), while 'sustainable development' refers to the holistic approach and temporal processes that lead us to the end point of sustainability" (Shaker, 2015).

Global sustainable development can be achieved through:

1. Coordinate sustainable development around the world by leading organizations and international organizations

2. Coordination of sustainable development at the level of the states of regions and local governments, the creation of appropriate local environmental law and the relevant control institutions

3. Sustainable development at the enterprise level

4. Participation in sustainable development at the individual level through appropriate patterns of consumption and awareness, attitudes and ecological responsibility.

At enterprise level, sustainable development is implemented in an ecological aspect by pursuing an integrated ecological product and process policy by monitoring environmental impacts throughout the entire production cycle, from raw materials extraction, transport, utilization, disposal and recycling. So many companies are involved in this activity, each of which is implementing its environmental policy at its own pace. An important concept that should be considered at the enterprise level is "eco-efficiency" It was introduced by the World Business Council for Sustainable Development (as an indicator of the economic value added by a firm in relation to its aggregated ecological impact. This idea has been popularised by the WBCSD under the following definition: "Eco-efficiency is achieved by the delivery of competitively priced goods and services that satisfy human needs and bring quality of life, while progressively reducing ecological impacts and resource intensity throughout the lifecycle to a level at least in line with the earth's carrying capacity" (De Simone, Popoff, 1997). Other, importantly related to this concept is the "sustainability performance", which is to determine the strategic development goals of an enterprise, taking into account the differentiated development principles and the extent to which they should be achieved in the business operations of an enterprise.

\section{Conclusions}

Nowadays, environmental management can no longer only be of local importance, as globalization processes have also embraced this area. The author distinguished and discussed six aspects of ecological globalization: proximity, interdependence, awareness, attitudes and 
responsibility, and interaction. Cooperation in the field of ecological globalization takes place in the process of global environmental management. It is coordinated through international conferences and institutions that provide relevant environmental resolutions and ordinances. They in turn affect the country-specific environmental laws and control institutions. Companies in turn must comply with relevant environmental regulations. However, the share of enterprises is not passive, however, by subordinating to certain environmental laws. Thanks to the technological processes of innovation and their implementation, they take an active part in influencing the environment in a global sense and thus also affect global sustainability. Since environmental protection and sustainable development are now an extremely important social and human resource, corporate environmental initiatives and innovations can be supported both locally (local and state) and by international organizations and programs.

\section{References}

Albrow, M., King E. (eds.) (1990). Globalization, Knowledge and Society London: Sage. [in English].

Buchenrieder, G., Göltenboth, A.R. (2003). Sustainable freshwater resource management in the Tropics: The myth of effective indicators, 25th International Conference of Agricultural Economists (IAAE) on "Reshaping Agriculture's Contributions to Society" in Durban, South Africa. [in English].

De Simone, L., Popoff, F. (1997). Eco-efficiency: The business link to sustainable development. Cambridge: MIT Press. [in English].

Möller, L. (2013). Międzynarodowa ochrona środowiska, (Kryński, A., Kramer, M., Caekleberg, A.F. (red.) Międzynarodowe Zarządzanie Środowiskiem. Warszawa: Oficyna. [in Poland].

Oczkowska, R. (2007). Przedsiębiorstwo na rynku międzynarodowym. Uwarunkowania strategii internacjonalizacji i globalizacji. Kraków: Krakowskie Towarzystwo Edukacyjne. [in Poland].

Poskrobko, B. (1998). Zarządzanie środowiskiem. Warszawa: PWE. [in Poland].

Shaker, R. R. (2015). The spatial distribution of development in Europe and its underlying sustainability correlations. Applied Geography, 63, 304-314. [in English].

Skorupka, S., Auderska H., Łempicka Z. (1969). Mały słownik języka polskiego. Warszawa: $P W N$. [in Poland].

Stoner, A.F., Freeman, R.E., Gilbert, D.E. (1198). Kierowanie. Warszawa: PWE. [in Poland]. Sztompka, P. (2005). Socjologia zmian społecznych. Kraków: Znak. [in Poland].

Zachara, M. (2012). Global governance. Ład międzynarodowy po zakończeniu stulecia Ameryki. Kraków: Wydawnictwo Uniwersytetu Jagiellońskiego. [in Poland].

Zatęski, P. (2005). Globalny system pozarzadowej administracji: Geosocjologia trzeciego sektora. Studia Polityczne, Vol. 17. [in Poland]. 